\title{
THE CAUSES AND TREATMENT OF COLLAPSE ON THE OPERATING TABLE*
}

\author{
J. G. Robinson, M D
}

STEDMan defines collapse as a condition of extreme prostration similar to shock and due to the same causes, often with the addition of a great loss of fluid. To the anaesthetist, collapse generally signifies one of two things: first, primary cardiac farlure, or, secondly, the more gradual deterioration of a patient's condition, which is conveniently described as shock and which, if severe and untreated, may lead to secondary cardiac fajlure Thus secondary fallure occurs because the patient has died whereas in primary falure the patient is still alive and will remain so for several minutes. Immediate vigorous treatment in this latter type should restore the heart action leaving the patient none the worse for his experience

Anaesthesia, as it is generally practised by anaesthetists, surgeons, or physicians falls into several well-defined groups The question of collapse will be considered as it occurs most commonly in each of the following groups.

A Inhalation Anaesthesia

B Conduction Anaesthesıa

(1) Spinal and Epidural Anaesthesia

(2) Regional Block Anaesthesia

(3) Local and Topical Anaesthesia

C Intravenous and Rectal Anaesthesia

\section{A Inhalation Anaesthesia}

In this type of anaesthesia, the most dramatic collapse occurs in the form of primary carduac fallure. Usually, in the early stage, the heart is either beating very feebly, in ventricular fibrillation, or quiescent

Primary cardiac fallure can occur in both normal and cardiac patients. This type of fallure or arrest may arise frorn marked vagal stımulation such as stimulation of the trachea or be due to traction on the hilar regions of the lungs, or on splanchnic and mesenteric plexuses or the broad ligaments 'It may result from anoxia produced by an over-dosage of the anaesthetic agent or by respiratory obstruction. Hypoxia and hypercapnia are important factors in potentiating the vagal effect on the pacemaker.

In 41 cases of primary cardrac fallure, Turk and Glenn (4) list the causes as follows.

Sudden death, either from the condition which brings the patient to the operating room or from a complicatıng medical condition, may sımulate primary cardiac arrest. Patients suffering from severe haemorrhage, trauma, toxaemia, or insulin shock form a part of this group. In any event, If, suddenly, no pulsations

-Presented as a Seminar in the Postgraduate Course, Department of Anaesthesia, University of Toronto

Can Anaes Soc T, vol 3, no. 3, July, 1956 
TABLE I

Primary Causes of Cardiac Arrest

\begin{tabular}{|c|c|}
\hline Cause & Number of Cases \\
\hline \multicolumn{2}{|l|}{ Vagal Strmulation } \\
\hline Direct & 4 \\
\hline Reflex & 1 \\
\hline \multicolumn{2}{|l|}{ Anoxia } \\
\hline Haemorrhage & 5 \\
\hline \multicolumn{2}{|l|}{ Obstructed airway } \\
\hline Anaesthesia & 2 \\
\hline Head mjury & 2 \\
\hline Coronary occlusion & 1 \\
\hline Sedation & 1 \\
\hline Drug ediosyncrasy & 2 \\
\hline \multicolumn{2}{|l|}{ Direct endocardial strmulation } \\
\hline \multicolumn{2}{|l|}{ Pnimary arrhythmia } \\
\hline \multicolumn{2}{|l|}{ Acute adrenal insufficiency } \\
\hline Uncertain & \\
\hline
\end{tabular}

can be felt and no sounds can be heard over the praecordium, then the diagnosis of primary cardiac fallure is made and no time must be lost in instituting artificial respiration and artificial circulation A thoracotomy is performed and the heart massaged while oxygen from the an'testhetic machine is administered by manual control through an endotracheal catheter, if one is already in place, or by a facepiece Fluids of any type may be administered intravenously under pressure Intracardiac infusion of epinephrine (3-5 cc of $1 / 10,000$ solution) may initiate rhythm after massage has been started although ventricular fibrillation may be produced if the myocardium is still anoxic

Ventricular fibrillation is often a product of light anaesthesia and frequently occurs early in induction or just before the moment of awakening. It may be closely associated with a sudden increase of epmephrine in the blood streameither endogenous or exogenous. It may also follow another cardıac arrhythmia The usual reasons for these arrhythmias are:

1. Severe oxygen lack

2. Stumulation of autonomic reflexes with the vagal nerve as the efferent pathway

3 Manipulation of the heart or great vessels

4 Temporary circulatory obstruction.

5. Over-dosage of anaesthetic agent

6 Excessive use of vasopressor drugs

7. Manipulation of epinephrine producıng tumours.

Treatment of ventricular fibrillation is, again. artificial respiration and circulation. Massage is instituted immediately to ensure good colour and tone of the heart muscle and then electrodes are placed on the heart to carry out the defibrillation technique Two or three shocks, each lasting about one second, 
are generally sufficient to bring the fibrillation to a stop and then massage and epinephrine treatment are instituted as for cardiac arrest. The usual defibrillating current required is $1-2$ amperes of a 60 cycle, 110 volt current. It has been shown in the dog heart that currents of less than one ampere regularly procluce fibrillation whereas the above-mentioned amperage stops fibrllation. Procaine hydrochloride injected into the right ventricle in amounts of $3-4 \mathrm{cc}$. of $\mathbb{l l}$ per cent solution bathed over the epicardial surfaces may also prove helpful in initiating normal rhythm where fibrillation has been prolonged. Brock and Milstein state that in a series of thirty cases of fibrillation they felt that procaine in doses of 50-200 mg. intravenously was effectıve in abolishing nine episodes of fibrillation. All these steps in the treatment of ventricular fibrllation may have to be repeated several times before normal rhythm is regained and maintained. However, it may also happen that i ecovery to normal rhythm may occur while resuscitative measures are being prepared.

Operative shock or progressive hypotension is often a prelude to secondary cardiac failure unless the contmung deterioration is reversed. A major fall in blood pressure may simulate primary cardiac fallure because of absent pulses, but cyanosis and pallor occur more slowly in the secondary form of failure. Often obvious haemorrhage or traction on viscera may be the clue to the cause of hypotension

The usual causes of secondary farlure can be enumerated as:

1. Loss of fluids through sweatıng, respiration, haemorrhage. extravasation.

2 Prolonged exposure to trauma.

3. Stimulation of traction reflexes.

4. Loss of heat from exposed viscera and cold inhaled vapours

5. Over-dosage of anaesthetic, etther relative or absolute.

6. Severe anoxia.

7. Sudden changes or extremes in positioning of patient.

8. Perforation of a viscus

Blood replacement is the treatment for haemorrhage; but plasma and plasma substitutes can be utlized until blood is avallable. Vasopressors, moderate head down position, adequate oxygenation, and intravenous fluids are the accepted quartet for treatment of increasing hypotension, provided the noxious stimulus or other exciting factor has been removed, and blood loss has not been excessive Levophed may be necessary during prolonged surgery or excessive trauma to maintan approximate normal blood pressure but should not be utilized as a substitute for blood replacement. Thus the avoidance of deeper anaesthesia than necessary, the prevention of loss of heat and moisture, the avoidance of rough handling of tissues, and the maintenance of a high alveolar oxygen level throughout the operation are the main points to be kept in mind, in order to prevent the onset of increasing hypotension. In a normal patient, surgical or anaesthetic shock need never be fatal, but in patients with marked myocardial degeneration, coronary stenosis, chronic debilitating disease with or without advanced age, death may occur rapidly. Thus the issue resolves itself into one of balance between cardiac effort and cardiac support in the matter of tissue oxygenation and replacement of blood or fluid loss. Jacoby, Flory et al (8) report a successful out- 
come in a case in which 54 pints of blood were given in $2 \frac{1}{2}$ hours to offset the blood loss during surgery. They also gave one gram of calcium gluconate for each 2-3 pints of transfused blood to offset the deleterious effects of hypocalcemia.

The crrculatory factors relevant to collapse in unhalation anaesthesia not only include accidents due to decreased blood pressure, but those due to increased. blood pressure as well Severe hypertension may be produced as follows

1 By rapid asphyxia which occurs occasionally during an anaesthetic and is augmented at the start by initial struggling and breath-holding.

2 A slow increase in blood pressure caused by poor technique which prevents adequate removal of carbon dioxide

3 Increased epmephıne in the curculation due to fear, excitement, and strugglıng.

4 Overhandling of a toxic thyroid gland or adrenal tumours.

These four factors may produce acute cardiac dilatation or rupture of a blood vessel. Cardiac dilatation may restrict coronary flow, causing the heart to stop, while rupture of a vessel may cause immediate death Obviously the treatment of these two conditions lies only in theil prevention with emphasis on smooth, quiet induction and the maintenance of a free all way with attention to adequate iemoval of accumulatıng carbon dioxide

Respuratory failure under general anaesthesia can be partial or complete but in either case, if allowed to persist long enough, will cause vasomotor collapse through prolonged anoxia. Respiratory falure can be considered as either central or peripheral respiratory failue

Central respiratory fallure is generally caused by

1. Overdose of pre-anaesthetic sedative

2 Overdose of the anaesthetic agent

3 Increase of intracranial pressure

One of the above factors may lead to serious trouble but a combination of two or more of these factors may well be disastious

When pre-anaesthetic medication has lowered the respiratory rate, the increased level of carbon dioxide in the blood will raise the normal respiratory threshold Hyperpnoea of induction as in vinethene or ether induction will lower the carbon dioxide level and respirations may cease. Anaesthesia in a closed circuit will maintain blood carbon dioxıde at more normal levels so that apnoea can be avoided. However, under prolonged closed anaesthesia elevated carbon dioxide levels may drop seriously at the conclusion of the anaesthetic with resultant hypotension and/or respiratory failure as is occasionally seen in so-called "cyclopropane shock" This somewhat rapid drop in blood pressure can be avoided by gradual elimination of the oprate, anaesthetic, and carbon dioxide towards the end of the operation by conversion to a high flow of nitrous oxide and oxygen in a semi-closed system.

Children, because of inadequate pre-anaesthetic sedation, often show hyperpnoea throughout induction with resultant blow-off of carbon droxide and precipitate anaesthesia which further depresses respiration Apnoea and cyanosis occur, and these are followed by frantic resuscitative measures on the part of 
the anaesthetıst. This situation can be avoided through adequate preoperative sedation and therefore quiet induction.

Any intracerebral or medullary pathology mav elevate the respiratory threshold so that further elevation by opiates before operation or administration of the anaesthetic may completely paralyse respiration

Peripheral respiratory interference occurs in such conditions as:

1. Breath-holding-due to durect irritating vapours.

2 Relaxation of jaw allowing tongue to occlude respiratory tract.

3. Layngeal spasm-due to drrect irrtation of vocal cords or from abdommal reflex origin.

These conditions may lead to apoplexy or acute cardiac dilatation or to the eftects resulting from prolonged hypoxia

4 Aspiration of debris during induction or anaesthesia, which can lead to partial or total collapse of lung with subsequent hypoxia, collapse, and death.

The usual causes for this accident are:

1 Vomitus-in accident cases, obstetrical patients, those with intestinal obstruction, or poorly prepared patients.

2 Excess mucus

3 Pus from pharyngeal or peritonsillar abscesses

4 Bronchrectasis or lung abscess

5 Haemorrhage from surgery or anaesthetic trauma to nose, throat, and mouth

6 Bioken teeth or suction tips

7 Sponges or pharyngeal packs

The use of lavage where a full stomach is suspected is a safety precaution that cannot be overemphasized Often, however, particles of undigested food will still remain in the stomach so that smooth induction, the presence of adequate suction, an operatung table that can provide immediate Trendelenburg, and an orotracheal cuffed catheter are all indispensable implements in the handling of the suspect "full stomach"

However, the above-mentioned accidents still occur and the restoration of pulmonary function is the prime concern in the institution of resuscitation. If no foreign obstruction is present in the pharynx or in the glottic region then intubation, oxygenation, and suction are the prime points $\mathrm{m}$ immediate resuscitation Bronchoscopy should be carried out to complete the removal of vomitrs, blond clots, or foreign material from the trachea or bronch. Anoxia during the bronchoscopy should be studiously avorded, since the patient's hypoxic state can easily be further aggravated during the insertion and manipulation of the bronchoscope.

Other pulmonary conditions which, if left unattended, cán lead to hypoxia and collapse are.

1 Internal or external paradox.cal i espu ation

2. Bronchopleural or tracheal fistula.

3. Bilateral pneumothorax

4 Acute emphysema.

5 Pleural effusion

6 Pulmonary oedema

External paradoxical respiration can be treated by providing an unobstructed 
orotracheal arrway. Internal paradoxical respiration occurs in the open chest and is handled by controlled respiration. Bronchopleural or tracheal fistula are generally accidentally produced and allow escape of vital oxygen and anaesthetic agent. High flow oxygen, intravenous anaesthesia, if necessary, and repair of the damage are the necessary points in the treatment. Bulateral pneumothorax may occur in surgery of the oesophagus, trachea, or the great vessels and controlled respiration via an endotracheal catheter is the bulwark against collapse. Acute emphysema following ball-valve obstruction of a bronchus may require bronchoscopy or bronchial exploration to relieve the obstruction. Rupture of a lung cyst following positive pressure by the anaesthetist may cause pulmonary collapse so that immedrate reparative surgery may be required before this complication progresses

Undiagnosed pleural effusion may be present in cardiac patients or patients presenting with sub-phrenic or pancreatic abscesses Respiratory embarrassment may become quite marked durmg or at the end of the operatıve procedure.

Pulmonary oedema is a serious complication which, fortunately, develops rarely. It is characterized by gentle wheezing and the appearance of pinkish flud in the tracheobronchial tree The usual causes centre around damage to pulmonary capillaries by

1. Prolonged shock.

2 High pulmonary intravascular pressure from cardiac dilatation or cardiac tamponade.

3. Excessive negative intratracheal pressure, 1 e respiratory obstruction.

4. Direct injury as in an anaesthetic explosion

5. Prolonged extreme head down position

6. Overhydration

7. Anaphylactic reaction

8. Congestive heart farlure

Treatment consists of tracheobronchial toilet and the application of slight positive pressure durmg expiration. Intravenous infusion should be stopped or slowed and the table tlted to a $30^{\circ}$ Fowler's position. Aminophylline ( $7 \frac{11}{2} \mathrm{gr}$ i.v.) should be given slowly and may be repeated if necessary If the oedema is considered to be cardiac in origin, then digitalization should be carried out with $0.5-1 \mathrm{mg}$ of digoxin which may be repeated if necessary Cortisone therapy may be required if oedema was due to explosion or anaphylactic reaction Phlebotomy and administration of hypertonic glucose may prove useful. If blood was administered during the surgical procedure, then a recheck of the blood grouping should be carried out.

There are many other accidents that can precipitate collapse under general anaesthesia, a few of which deserve separate mention

(1) Tracheal Collapse This may occur following removal of a large thyroid gland with resultant respiratory obstruction. Intubation either should be done at the start of the thyroid operation or at least be anticipated throughout the procedure

(2) Convulsion Deep ether convulsions occur chiefly in children but may occur in adults as well They may also occur in light anaesthesia Controversy 
exists as to whether deficiency or excess of carbon dioxide is the chief cause although quite often a febrile condition co-exists Regardless of the cause, treatment consists of removal of the anaesthetic, administration of oxygen, and the intravenous administration of Pentothal.

(3) Venous or Arterial Air Embolism These conditions prevent adequate cardiac emptying and filling with manked reduction in cardiac output and may lead to shock or immediate death. Massive amounts of air may be sucked or forced into the circulatory system at ter intravenous fluids are exhausted. Air embolısm can also occur in neurosurgery and pelvic surgery and may lead to sudden cardiac failure. The patent should be placed in the supine position, turned on the left side, and given oxygen If a normal heart beat is not restored, a needle puncture of the right ventricle should be performed in an attempt to aspirate the air, and if this tarls, the air should be aspirated through a thoracotomy incision and massage instituted if necessary.

(4) Ether Accidents (a) Liquid ether in lungs may occur when the ether vaporizer is wrongly connected. Viclent pulmonary congestion, oedema, and death may ensue. This apparatus should always be tested before use. The use of a Flagg can will allow ether to be spilled into the lungs if it is tipped. These cans should always be strapped to the table after the patient is positioned. (b) Bolling ether is another factor Some vaporizers have a heating arrangement to vaporize ether more efficiently, especially when adults are being anaesthetized with pharyngeal insuffation When anaesthesia deepens the hook should be removed from the mouth-1t is not sufficient to turn off the air current.

(5) Miscellaneous Explosions or fire, metabolic emergencies, mechanical or human errors in anaesthetic techniques are mentioned for the sake of completeness and shquld not be minımized.

\section{B Conduction Anaesthesia}

Toxic reactions to the diugs employed in the use of spinal and epidural anaesthesia, regional and local anaesthesia are due either to: sensibvity to the drug or to a high blood level of the drug. Sensitivity to the drug provides less than 2 per cent of the reactions seen and the wheals, itching, hypotension, and asthmatic breathing are treated symptomatcally

High blood levels of the agent used account for more than 98 per cent of the reactions seen and these reactions are more severe in nature. High levels arise manly from inadvertent intravascular injection or injection into a highly vascular area The use of hyaluronidase spreads the absorptive area and may give excessively high blood levels Errols in dosage and faulty detoxification mechanisms in the patient also rase the blood levels

The signs and symptoms are central in origin and are listed as follows:

1. Mental-drowsiness, dullness and coma.

2. Cardiovascular-Tachycardia progressing to bradycardia and hypotension, possible cardiac arrest.

3 Respiratory-Depressed shallow respirations, dyspnoea or bouts of apnoea.

4. Neurological-Minimal twitchıng or generalızed convulsions. 
These signs may be immediate or delayed up to thisty minutes. Thus the anaesthetst must be prepared to administer oxvgen, vasopressors, atropine, barbiturates, and even perform cardrac massage if necessary for at least one half hour after the block has been given It cannot be overstressed that $1 \mathrm{~m}$. mediate access to operatıng room facllities is of prime importance whenever block procedures are contemplated because of the possibility of toxic reactions to the drugs employed.

In the first half hour of spmal andesthesia the most dramatic form of collapse is that of a combined respiratory and circulatory depression. The tone of the entire vascular bed is maintained both by the action of the sympathetic innervation and by the tone of the voluntary muscles Thus the combined effect of sympathetic paralysis, hypoxia due to respiratoly depression, and loss of muscular tone is to produce curculatory and respiratory depression which varies directly as the height of anaesthesia progresses This condition may go on to severe collapse and cardiac slowing by paralysis of the cardiac accelerator nerves

Treatment consists of

1 Intravenous infusions of salme or glucose with vasopressor administration through the rubber tubing

2. Oxygen administration by mask with positive pressure

3. Horizontal positioning of patient since head up or head down positions may further advance the hypobaric or hyperbarı spread of the anaesthetic solution or conversely with result in imperfect anaesthesia so that added agents will be required after normal tension has been restored

With profound vasomotor and respiratory collapse cardiac standstill may occur. Treatment consists of

1. Instant recognition

2. Scultetus position to provide blood for the vital centres

3 Cardiac massage

4 Oxygen mask under positive pressure-later by endotracheal tube

Respiratory and circulatory collapse under spinal anaesthesia can occur individually or combined and it must be stressed that either can set up a chain of events that will bring about the other

Hypertension may occur with resultant cardiac dilatation, rupture of a cerebral vessel, or cardiac arrest. The cause may be asphyxıa, adrenalin excess, too much sympathetic stumulation prophylactically or from the toxic effect of the vasoconstrictor agent used Treatment of hypertension consists of assisted respirations in a closed circle filtre, ammophyllme $33^{3} \mathrm{gr} .1 . \mathrm{W}, 50 \mathrm{mg}$ doses of Pentothal, or If available a nitroglycerm tablet $1 / 100$ gr placed under the tongue

Epidural anaesthesia can produce hypotension to about the same degree as spinal anaesthesia although respiratory paralysis is not as marked Inadvertent puncture of the outer meninges and flooding of the canal with the agent used may produce spinal anaesthesia past the foramen magnum with profound vasomotor and respiratory collapse. This same complication may also occur in stellate ganghon block, thoracic or lumbar paravertebial block, caudal block, and even in a brachal block The usual precautions of asprration, followed by the injection of a small amount of the drug and several minutes' scruttny for any untoward 
reactions, should always be taken. In the event of a misadventure, treatment is the same as that already outlined for spinal curculorespiratory collapse.

The use of topical anaesthetics such as cocaine, butyn, pontocaine; nupercane as employed in rhinology, laryngology, ophthalmology, and genito-urinary procedures, is fraught with the same dangers as those encountered in regional or local block procedures With regard to t le use of barbiturates before operation to offset these toxic phenomena, Moore (2) is of the opinion that barbiturates given before operation are useful onl $\gamma$ to allay apprehension. Moore states that to prevent a toxic reaction, barbiturates would have to be given in anaesthetic levels Stumulation of the central nervous system, progressing to eventual depression and paralysis of respiratory and vasomotor centres, is the usual sequence of signs of drug toxicity. The treatment for such reactions consists of oxygen. suction, vasopressors, and small doses of intravenous barbiturates to stop convulsions

\section{Rectal and Intravenous Anaesthesu}

The relative or absolute over-dosage of anaesthetic agents in rectal or intravenous anaesthesia constututes the main cause of mishaps in these forms of anaesthesia. Barbiturates by rectum or intravenously can cause profound respiratory and circulatory collapse and the treatment is supportive. Other forms of rectal anaesthesia produce their ill effects through respiratory depression and resultant anoxia Intravenous procaine carres with it the dangers of toxic manıfestations and in higher doses may lead to cardio-respiratory collapse thiough its action on cential and autonomic nervous systems

\section{SUMMARY}

This article has been designed to review some of the more impor tant forms of collapse on the operating table and m most instances the cause and treatment of each form of collapse have been outlined briefly Collapse under inhalation and conduction anaesthesia has received the bulk of attention in this review since rectal anaesthesia is not a common procedure and intravenous anaesthesia in all its newer forms was considered to be beyond the original scope of this article Individual surgical techniques which in themselves might prelude collapse were purposely omitted and instead an effort was made to keep the subject within the anaesthetıst's domain

\section{RÉSUMÉ}

Nous avons passé en revue les dıfférentes formes de collapses pouvant survenı sur la table d'opération ainsı que leurs causes et leurs traitements, nous avons envisagé le problème selon qu'ils surviennent alı cours de $(a)$ l'anesthésie paı inhalation; (b) l'anesthésie loco-régionale, $(c)$ l'anesthésıe rectale et intraveineuse

Sous anesthésie générale, nous avons l’impressıon que la défaillance cardiaque primitive survient fréquemment à la suite d'un effet vagal su le centıe d'automatısme résultant d'une stımulation vagale soit directe soit réflexe L'anoxie et l'hypercapnée sont des facteurs importants quand survient la défaillance cardia- 
que primitive. Une complıcatıon médıcale ou chirurgicale peut également produire le même tableau clinique d'arrêt cardiaque. Les premiers gestes de la resuscitation sont les suivants: le dragnostic précoce, la thoracotomie, le massage cardiaque, l'oxygène sous pression et l'adrénalıne intracardiaque si nécessaire. La fibrillation ventrıculaire survient sous anesthésı légère, en présence de quantité excessive d'adrénalıne, en déficience d'oxygène ou, encore, à partır d'une autre arythmie; on convertut cette fibrillation en arrêt cardiaque par la défibrillation électrique pus on institue le tratement de l'arrêt cardiaque. Certains auteurs ont employé avec succès de la procaine à 1 pour cent soit en injections intra. cardiaques (3-4 cc.) solt en injections intraveineuses (50-200 mgm.) dans le but de resttuer un rythme normal lorsque la fibrillation s'est prolongée.

La défallance cardıaque secondaire est une autre sorte de collapse, elle peut survenur au cours de l'anesthésie générale et elle est le résultat d'une aggravation progressive de l'état du malade Cette sorte de collapse peut résulter soit d'une perte de liquides, d'un traumatısme prolongé, de réflexes de tractıon, soit d'un surdosage anesthésique surtout si ces facteurs ne sont pas contrôlés souvent Dans ces cas, il ne faut jamais employer de vasojpresseurs à la place de sang ou de plasma Au cours de cette sorte d'anesthésie, il peut survenir, à̀ l'occasion, une hypertension marquée Une élimination inadéquate du gaz carbonique, de l'appréhension et de l'agitation, des manipulations exagérées d'une thyroıds toxique ou des surrénales peuvent conduire à cette situation et causer une dilatation du cœur ou la rapture d'un vaisseau.

Sous anesthésie générale, la défaillance partielle ou complète de la respiration, pour peu qu'elle se prolonge, peut également entraîner un collapse circulatorre par anoxie prolongée La défaillance respiratoire centrale peut survenir à la surte de surdosage de la prémédication ou de l'agent anesthésique ou encore d'une augmentation de la pression intracranienne La défaillance respiratorre pérphérique est plus fréquente, elle comprend plusieurs formés d'obstruction des voies respiratorres, mécaniques, physiologıques ou pathologıques, obstructions qui peuvent rédure ou empêcher l'oxygénation

Avec l'anesthésie loco-régionale, on observe occasionnellement des réactıon is aux drogues employées Ces réactions apparassent dans les cas de sensibilité particulière aux médicaments ou lorsquill y a un taux élevé du médıcament dans le sang Moins de 2 pour cent des réactions anormales sont dues à une sensibılité spéciale et elles peuvent ètre trartées symptomatıquement, tandıs que 98 pour cent de ces réactions sont provoquées par un surdosage et elles peuvent être sérieuses. On peut observer des manifestations psychiques cardiovasculaires, respiratorres et neurologiques dont le tratement requiert de l'oxygène. des vasopresseurs, de l'atropine, des barbituriques et, dans un nombre de cas plutòt restreint, le massage cardıaque peut devenır nécessare En conséquence, quand on projette de farre un bloc, il faut toujours avoir à sa portée les facilités dont on dispose dans les salles d'opérations

Au cours de la rachianesthésie, la complication la plus dramatique est le collapse simultané de la circulation et de la respiration. La bradycardie peut aussi devenir un facteur important Le traitement dolt tendre à lutter contre l'hypotension et la manque d'oxygène. L'hypertension et ses complications peu- 
vent avoir pour causes: le manque d'oxygène, l'excès d'adrénalıne, endogène ou exogène, ou encore, une stimulation sympathique prophylactique trop intense. Les blocs épıduraux égallement peuvent produire de l'hypotension; toutefois les collapses plus sérieux qui surviennent sont dus à l'inondation imprévue de l'espace sousarachnoidien par l'agent anesthésique. Cette éventualité peut également se produire à l'occasion d'un blocage du ganglion' étoilé, d'un blocage paravertébral thoracique ou lombarre, d'un blocage caudal ou brachial. Pour prévenur cette inondation subarachnoıdınne, les détails importants sont: l'aspiration, l'injection de petites quantités et des pérnodes d'attente

\section{REFERENCES}

1 Guedel, Arthur E Inhalation Anaesthesia Macmillan (1951)

2 Moore, D C Regional Block. Springfield Thomas (1953)

3 Adriani, J \& Evangelow, M Complications of Regional Anaesthesia Anesth \& Analg 3496 (1955)

4 Turk, L N \& Glenn, W L Cardiac Arrest New England J Med., 251 795-803 (1954)

5 Brock, Sir Russell \& Milsterr, B B Ventricular Fibrillation during Cardiac Surgery Guy's Hospital Reports 1033 (1954).

6 Fortin, G \& LÉtienne, R. Prophylazis and Treatment of Cardiac Arrest Canad Anaes Soc J, 124 (1954)

7 Bergner, Robert P Cardiac Arrest Some Etiological Considerations Anesthesiology $16 \quad 177$ ( 1955$)$

8 Jaсовy, J J, \& Flony, F A et al Safety in Surgery Anesth \& Analg., 34346 (1955) 